\title{
Guidelines for transformation of trams to the light rail system in Sarajevo
}

\author{
Mustafa Mehanović \\ University of Sarajevo, Faculty of Traffic and Communications, Zmaja od Bosne br. 8, Sarajevo 71000, Bosnia and Herzegovina
}

\begin{abstract}
The transport of the tram system on a high capacity corridor in a narrow urban area with increasing demand has become limiting both in terms of capacity and in terms of quality improvement. In this sense, the tram system in Sarajevo, as the primary system of city passenger transport, for many years, requires improvement in order to meet demand. The lack of clear strategies and plans for improving the primary transport system results in interventions of short-term investments in the maintenance of the infrastructure and suprastructure of the classic tramway of outdated and abandoned technology. In this way, the system is brought into a state of very unreliable and unsafe work. On the other hand, it is obvious that the development of individual motorized traffic has led to the fact that the common route has worsened the quality and safety of driving. The paper presents basic guidelines and aspects for the transformation of the classical tram in Sarajevo to the Light Rail System that can reach the fast city railway with the quantity and quality of the offer.
\end{abstract}

Keywords: Tram System, Public Passenger Transport, Light Rail System, Infrastructure, Suprastructure

\section{Introduction}

Public city transport of passengers in Sarajevo is performed by the systems Tram, Trolleybus, Bus, Minibus and Inclined elevator. About 50\% of the transport was realized by the tram system. Tram lines extend through 4 municipalities in the inner city area and the municipality of Ilidža, which is close to city municipalities in terms of population and facilities, but is geographically diverse and its center is at a greater distance from neighboring municipalities compared to the distances of city centers.

During the period from 1885. the tram subsystem developed into the main backbone of Sarajevo's traffic system. The presence of trams on the main corridor, Baščaršija - Ilidža, as well as the configuration of the terrain has greatly contributed to the development of the city being extremely linear.

The maximum performance of the tram subsystem was recorded in 1991, when about 130 million passengers were transported, about $50 \%$ of the total number of transported passengers in Sarajevo.

The number of inhabitants in the Sarajevo Canton has been slightly increasing since 2000 , so that in 2013. the population was about 438 thousand, and in the four city municipalities it was about 291 thousand. The Sarajevo
Canton Development Plan envisages an increase in the number of inhabitants in both urban and suburban areas.

The requirements of passengers on certain sections of the tram corridor in peak load produce such a capacity offer that the intervals of movement and frequency of the vehicle have reached the limit values, e.g. the tram movement interval is $1.1(\mathrm{~min})$ at the intersections $\mathrm{C}-\mathrm{C}$ and D-D (Figure 1). The traffic cycle of traffic lights at intersections is 1 ( $\mathrm{min})$ and $50(\mathrm{sec})$ per phase, respectively, and today it is a common cause of tram delays. On the sections of the tram line, there is a need to speed up the transport, and thus to reduce the driving time of passengers. Meeting the needs of users is imperative and in the transformation of public transport it is necessary to provide users with attractive, comfortable, fast and affordable public transport with the least investment and lower operating costs. Most cities are struggling with this problem with varying degrees of success, and it also needs to be talked about and solved very systematically in Sarajevo.

The existing passenger transport management system in Sarajevo, due to its inertia and relatively high labor costs, cannot adequately respond to passenger requirements. For these reasons, it is necessary to approach the planning and construction of a new system. 
There is no doubt that the tram should be the backbone of the public transport system in the future as well. The development of the city, in the spatial and economic sense, is only possible if it is accompanied by an appropriate transport system. The Light Rail System concept has entered a number of projects for urban areas and in other European countries, albeit under different conditions depending on local occasions.

In Sarajevo, the characteristics of the existing tram need to be improved, in order for the transport service to be attractive and competitive in relation to transport by private cars. Reducing the share of private car use should not be based on "pressures" but on a better offer of public transport services.

\section{Analysis of the condition of the transport system on the high capacity corridor in Sarajevo}

The possibility and need for the transformation of the existing tram system in Sarajevo into a high-capacity corridor must be considered through the parameters that describe the demand for transport and supply of capacity on the corridor Baščaršija - Ilidža. From the analysis of business indicators and the current relationship between supply and demand of public urban transport, it is possible to provide guidelines for how to plan indicators relevant to the management of the transport process [1].

\subsection{Transport requirements - demand}

Transport requirements depend on a number of factors, and for this analysis the following are singled out [2] [3]:

- Significant contents as factors of production and attractions by zones - municipalities connected by tram lines

- Transport requirements on tram lines at peak hours

- Characteristics of tram stops (characteristic stop of the Island)

- Population forecast.

Significant contents of the Municipality of Stari grad are: High concentration of banks, financial institutions; Consulting and design houses; Representative offices of world famous companies; Exclusive shops; Specialist catering facilities; All inner courtyards "unconditional apartments", basements, ground floor, basements, built in the Austro-Hungarian era, have been renovated and filled with new business facilities.

The Municipality of Centar is an area of high concentration: Banks; Consulting and design houses; Representative offices of world famous companies; Exclusive shops; Specialist catering facilities; Public institutions; Institutions of the State of Bosnia and Herzegovina, the Federation of $\mathrm{BiH}$, Sarajevo Canton, the City of Sarajevo and the Municipality of Centar.

Significant facilities of the Municipality of Novo Sarajevo are: Modern traffic terminal at the location of the railway and bus station; Modern University Center; Business facilities of the largest Sarajevo and world companies; Hotels; Numerous cultural contents that ensure the continuity of the urban fabric; Representative social infrastructure facilities; Business facilities.

Significant contents of the Municipality of Novi grad are: Representative objects of social infrastructure; Business facilities; In the area of Stup, there is a secondary center with functions complementary to those in the city center; Work zones in the wider area of Stup are far more economically and ecologically efficiently used; In addition to public and state-owned companies, there are also a large number of small and medium-sized private companies whose programs are mutually complementary and which, thus concentrated, enable far greater effects on various grounds.

Significant contents of the Municipality of Ilidža are: In addition to public and state, there is a large number of small and medium private companies; Work zones in the wider area of Stupa; Full economic and ecological valorization of all natural, inherited, built, traditional and other values of this area, including the slopes of Bjelašnica.

Maximum passenger flows are at peak hours in the morning from 7.30 to 8.30 . Passenger flows are given by sections at intersections: A-A: $5300(\mathrm{p} / \mathrm{h}) ; \mathrm{BB}: 7500(\mathrm{p} /$ h); C-C: 9100 (p / h); D-D: 9100 (p / h); E-E: 6800 (p / h) and F-F: $1800(p / h)$, Figure 1, Table 1. Utilization of the number of seats in the opposite direction, ie. from the city center is $50 \%$ or less depending on the section.

The Otoka stop is located on the section of the tram route marked with section B-B. On the dream of recording during one characteristic day (Saturday) in the direction of Baščaršija - Ilidža, data were obtained which represent the dependence of the number of passengers arriving at the stop in time from the last departure of the vehicle from the stop. The average vehicle arrival interval is 2.4 (min). On average, the number of passengers arriving at a stop during one interval is 17 .

\subsection{Transport capacities - service offer}

The number of transported passengers by type and total at the level of KJKP GRAS, daily and annually, throughout the year shows that close to $50 \%$ of passengers in annual movements use the tram. All tram lines are on the same route. Only lines 1 and 4 towards the railway station have a branch perpendicular to the base route (Figure 1). 
Table 1. Data on tram lines in Sarajevo (2010 with majority two-piece vehicles)

\begin{tabular}{|c|c|c|c|c|c|c|}
\hline No & Line name & 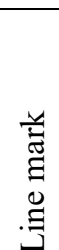 & 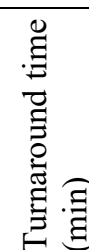 & 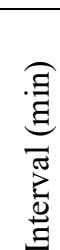 & 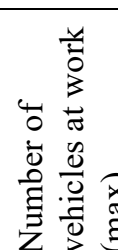 & 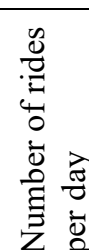 \\
\hline 1. & $\begin{array}{l}\text { Baščaršija - } \\
\text { Željeznička stanica }\end{array}$ & 1 & 30 & 10 & 3 & 134 \\
\hline 2. & $\begin{array}{l}\text { Baščaršija - } \\
\text { Čengić Vila }\end{array}$ & 2 & 40 & 6,7 & 6 & 173 \\
\hline 3. & Baščaršija - Ilidža & 3 & 76 & 4 & 19 & 501 \\
\hline 4. & $\begin{array}{l}\text { Željeznička stanica } \\
\text { - Ilidža }\end{array}$ & 4 & 60 & 20 & 3 & 81 \\
\hline 5. & $\begin{array}{l}\text { Baščaršija - } \\
\text { Nedžarići }\end{array}$ & 5 & 60 & 7,5 & 8 & 211 \\
\hline 6. & Skenderija - Ilidža & 6 & 60 & 7,5 & 8 & 180 \\
\hline 7. & $\begin{array}{l}\text { Skenderija - } \\
\text { Nedžarići }\end{array}$ & 7 & 48 & 6 & 8 & 120 \\
\hline & TOTAL: & & & & 55 & 1400 \\
\hline
\end{tabular}

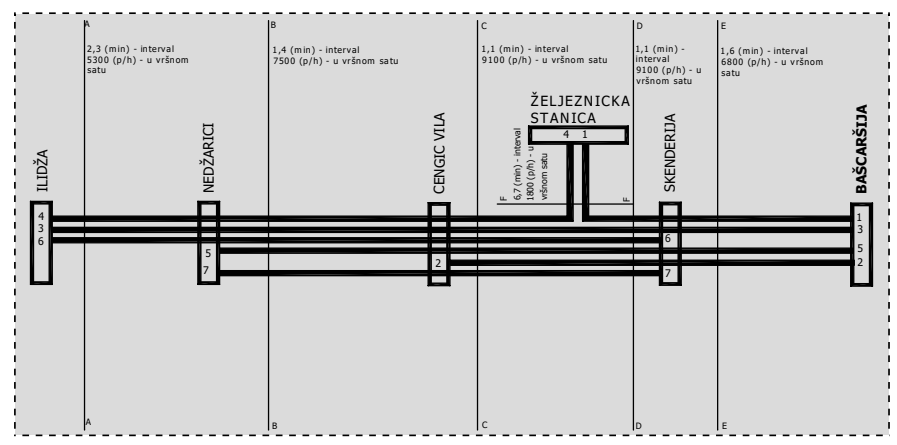

Figure 1. Characteristic cross-sections of tram sections

Table 2. Transport efficiency

\begin{tabular}{|c|c|c|c|c|}
\hline $\begin{array}{l}\text { Transport } \\
\text { system }\end{array}$ & $\begin{array}{c}\text { Transport } \\
\text { speed } \\
(\mathrm{Km} / \mathrm{h})\end{array}$ & $\begin{array}{l}\text { Average } \\
\text { daily } \\
\text { working } \\
\text { hours of } \\
\text { lines (h) }\end{array}$ & $\begin{array}{c}\text { Passengers } \\
\text { transported } \\
\text { for an hour of } \\
\text { line work } \\
(2010 . \text { g.) }\end{array}$ & $\begin{array}{l}\text { Efficiency* } \\
\text { (place-km/h) }\end{array}$ \\
\hline Tram & 17 & 16 & 14692,36 & 249770,14 \\
\hline Trolleybus & 18 & 16 & 4757,64 & 85637,50 \\
\hline Bus & 20 & 12 & 12137,96 & 242759,26 \\
\hline Minibus & 20 & 10 & 3458,33 & 69166,67 \\
\hline
\end{tabular}

Table 2 show transport efficiency by sectors in KJKP GRAS for 2010, where instead of transport power the number of transported passengers per hour was used. The average daily working hours of the line are different for each type of transport, and the tram and trolleybus have the longest average working hours of the line - 16 hours. Figure 2 show supply service in the tram system (number of seats offered per hour on all lines).

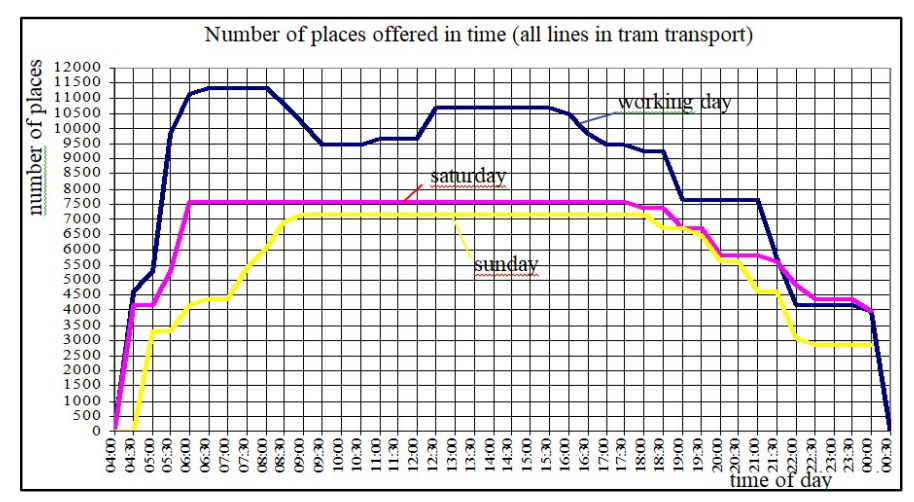

Figure 2. Supply service in the tram system (number of seats offered per hour on all lines)

\subsection{Basic elements of the quality of the tram transport service offer}

The percentage share of walking time of passengers in the gravitational area of tram lines is given in the Table 3 .

Table 3. Walking time to and from the stop

\begin{tabular}{|c|c|c|}
\hline \multirow{2}{*}{$\begin{array}{c}\text { Walking time } \\
\text { (min) }\end{array}$} & \multicolumn{2}{|c|}{ \% of total walking } \\
\cline { 2 - 3 } & to stop & from stop \\
\hline 5 & 59,3 & 58,2 \\
\hline 10 & 27,0 & 27,0 \\
\hline 15 & 8,0 & 8,6 \\
\hline 20 & 3,5 & 3,6 \\
\hline 25 & 0,4 & 0,5 \\
\hline Over 25 & 1,8 & 2,1 \\
\hline
\end{tabular}

The average ride length is the average distance traveled by one passenger on a line or the entire network. Values vary by hours per day as well as by days of the week. Extensive recordings in the form of counting or surveying passengers are required to determine the value of the average driving length (a representative sample for our conditions is proposed about $10 \%$ of the total number of passengers), and based on recordings from 1989, 1998, 2001 and 2003. performed the following estimates of the average length of driving during the day for tram lines from 1.85 to $3.75 \mathrm{~km}$, an average of $2.95 \mathrm{~km}$ [4].

\section{Examples of Light Rail Systems (LRS) and their role in the transport system}

Depending on the size of the city, its urban development, the degree of general mobility and mobility in public transport, the degree of motorization achieved and the income of the population, the LRT system can take on a large number of different roles within the overall passenger transport system. This is also due to the high 
degree of flexibility of the LRT, through a wide range of possible capacities on one corridor (from 2,000 to 40,000 passengers per hour) as well as flexibility in tracing short tunnels or overpasses.

From the wide range of possible roles of LRT, the following can be singled out:

1. The LRT system serves medium-sized cities as the main carrier of transport. The bus and / or trolleybus subsystem and the suburban railway system are subordinated to it. Typical examples are the cities of Hanover, Stuttgart, Manchester, Nantes, Grenoble, Zurich, Rouen, The Hague, San Jose, Sacramento, Zagreb, Melbourne.

2. Chain system as a supplement to the metro system on the routes to the city center, in large cities, with strong coordination with other subsystems. The best examples are the cities of Munich, Berlin, Amsterdam, Frankfurt, Brussels, Prague, Budapest, Bucharest, Milan, Hong Kong, Rome.

3. LRT system that connects orbital or tangential directions in large cities, without entering the city center. Examples are the cities of Paris, London, Moscow, Stockholm. Some cities are considering re-entering the city center.

4. LRT system that is insufficiently developed or suppressed from the city center, with a secondary role in the number of transported passengers, such as in Birmingham, Belgrade.

5. LRT system that is gradually transformed in certain directions into a metro system. This strategy is also called pre-metro. The best example is Brussels, Charleroi, Tel Aviv.

6. LRT systems that use railway routes and facilities on the periphery, and LRT routes within the urban area. The best examples are Saarbrücken, Karlsruhe, Toronto, Zwickau, the Paris region.

7. LRT, which participate in a significant percentage in regional transport, through independent routes that connect cities with regional centers. Examples can be seen in Switzerland, Austria, Belgium, France, Germany, Italy, Brazil, Japan, Spain, USA, etc. It is often a matter of favoring the use of LŠS in order to facilitate overcoming difficult field conditions, thanks to the advantages of LŠP in relation to the classical railway.

In Karlsruhe, the existing tram network connected to the German Railways (DB) suburban lines was expanded and put into operation in 1996. This example was quickly adapted in other German cities, starting with Saarbrücken in 1997. Stuttgart, Cologne, Frankfurt, Hanover, Dusseldorf and Dortmund began intensively introducing a light rail transport system. In a total of 16 cities, tram lines were upgraded to light rail systems (Saarbrücken, Kassel, Aachen - Figure 3).
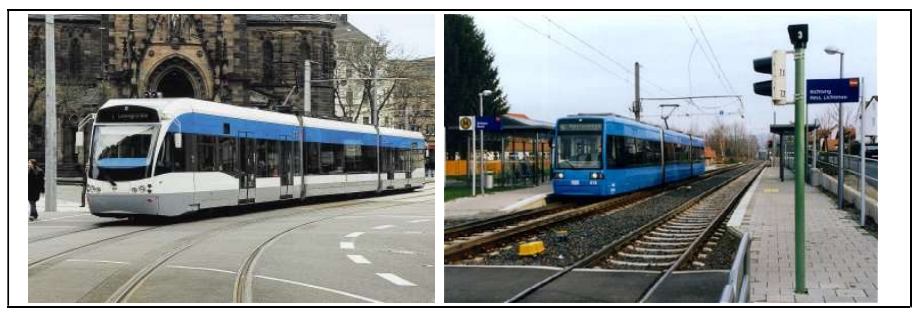

Figure 3. Lakošin system in European cities (Saarbrucken, Kaasel)

The tram system in Sarajevo is the main carrier of transport (it can be classified in the group of cities under number 1) on the influential corridor. Bus and minibus systems from the peripheral areas of the city provide transportation to the characteristic tram stations. The trolleybus system with some lines supplies trams, and one line stretches along the tram route at a distance of 300 to $1000 \mathrm{~m}$ (on the other side of the river).

\section{The scope of the concept of building a Light Rail System}

When the existing system of the classic tram cannot meet the demand for transport on high-capacity corridors in terms of quantity and quality, there is a need for a comprehensive analysis of the situation and the development of proposals for measures to improve the situation. Since the construction of the metro system cannot be justified in smaller cities the size of Sarajevo, the justifications for the transformation of the classic tram into a light rail system should be reconsidered. Justification is sought in the significantly lower costs of construction and operation, and the very large capacity observed in relation to the metro [5] [6].

The system construction project needs to cover the following segments in detail:

1. System line location

2. The concept of work

3. Vehicles of the Laško system

4. Power supply

5. Telecommunications

- Radio system

- Fiber optic system

- Simultaneous digital hierarchical system

- Localization system

- Traffic signs and signal lights

- Direction selection system

- Closed television control system

- Management Center 
- Stand equipment

6. Depot and terminals

7. Automatic ticket payment system

8. Contract organization and work

- Company concession

- Company operation

9. Financing models

- Downloads

- Profit and loss projection

$>$ Costs (Investment costs; Operating and maintenance costs)

$>$ Income (Projected operating income; The projected price of the ride and ticket; Projected operating income)

$>$ Profit and loss projection

$>$ Cash Flow projection (Financing of capital expenditures; Projected financing; Projected cash flow)

10. Project evaluation

- Internal rate of return to shareholders

- Financial review

11. Supporting documentation.

\section{Guidelines and rules in the construction and use of Light Rail Systems}

Until the 1930s (in Germany since 1934), trams, as well as light rail and underground railways were covered by the same regulations as the main railway lines, and when necessary, road traffic laws were taken into account. Since then, many cities have decided to set aside special regulations for the Light Rail System ("LRT-Light Rail Transit", "Straßenbahnen"), and then for street trams in order to cover all key issues of construction and operation of these transport systems.

Guidelines for the construction and operation of the LRT system include [7]-[9]:

1. Operations Management

- Carrier's executor

- Operations managers

- Certificate of Operations Manager

2. Work staff

- General conditions for operational staff

- Special requirements for traffic staff

- Training and testing of drivers and traffic staff

- Behavior during duty

- Behavior during illness.

3. Operating installations

- Line route

- Stripe shape

- Constant time
- Defining a "Clean Area"

- Security zones

- Crossing levels

- Signal installations

- Driving safety installations

- Technical information installations (communications and passenger information systems)

- Power installations

- Installations for contact lines

- Return current systems

- Lighting installations

- Pipelines

- Bridges

- Tunnels

- Stop places (stations)

- Escalators and strips

4. Vehicles

- Vehicle design

- Vehicle dimensions

- Drive

- Brakes

- He's pulling

- Traction and braking - control

- Busbars and inverters

- Warning and indicator installations

- Fuses

- Couplings

- Passenger door

- Driver's cabins

- Interior lighting, heating and ventilation

- Information installations

- Signs and markings

- Emergency equipment

5. Operations

- Traffic control

- Permitted speeds (speed limits)

- Signals (including signs, indicators and beeps)

- Recruitment of operational staff

- Hiring a vehicle

- Vehicle operation

- Working with road traffic

- Defective vehicles

- Maintenance of installations and vehicles

- Use and access to operating installations and vehicles

- Activities that jeopardize operational security

6. Procedural formalities

- Checking the accompanying documentation for the construction of installations 
- Supervision of construction works

- Acceptance (by the authorities)

7. Violations, Conclusions and Transitional Provisions (from previous regulations)

- Violations

- Entry into force and transitional provisions.

6 The course of modernization of the tram system in Sarajevo and the possibility of implementation in accordance with the guidelines International Association of Public Transport (UITP) for the development of Light Rail Transport (LRT)

Guidelines for the development and construction of new LRT systems should help those who are active in the field of transport but are not familiar in detail with the specifics of LRT, such as city planners, architects, traffic technologists, etc. As a result of this work, three documents are created, namely: level I, level II and level III [7].

Level I document contains the basic principles of LRT and the sequence of activities in the project implementation process. The interdependencies of individual phases of development and recommendations on streamlining activities and shortening the overall implementation of the project are presented.

Level II document contains more detailed chapters related to the planning of the new system, the process of evaluation and detailed design, synchronization with other infrastructure and the provision of financial resources.

Level III document presents the entire tender documentation for the procurement of new vehicles, a detailed presentation of determining the construction costs or determining the expected operating costs.

UITP represents the interests of carriers, local authorities and related industries towards other bodies and institutions within the United Nations and other international organizations and promotes the international dimension of public transport, starting from the fact that only through mutual cooperation of local authorities, carriers and industry can achieve optimal LRT development.

Based on the above, directions for further action on the introduction of the Champions League in Sarajevo can be given. The concept starts from the goals of the development of the Sarajevo Canton and maintaining continuity in the development of public urban passenger transport (UPPT):

- An integrated approach to development at the level of the Canton and the wider region
- Priority to the development of electric traction

- Modernization of the vehicle fleet and infrastructure

- Giving maximum priority to UPPT

- Application of central management and control of UPPT and introduction of ISO quality system

- Greater and more concrete financial support from Sarajevo Canton.

Based on the experience of cities of approximate size, the existing tram system in Sarajevo, in order to increase transport speed and efficiency, should implement the transformation in the following directions:

1. Introduction of a priority system at signalized intersections

2. Establishment of transfer points at intersections with other modes of transport and training of other stations for faster change of passengers

3. Construction of the first phase of new shares, e.g. extension to Dobrinja

4. Construction of the second phase of new sections, from Ilidža to Hrasnica and the branch from Dobrinja to the Airport

5. Construction of the third phase through the construction of a tunnel section in the city center and 2-3 underground stations.

6. Introduction of an integrated tram-train system for direct connection of suburban settlements with the city center [10]. A graphical presentation of these activities by stages is given in Figure 4.

The construction of a light rail system in Sarajevo would create conditions for transport management on the high-capacity corridor.

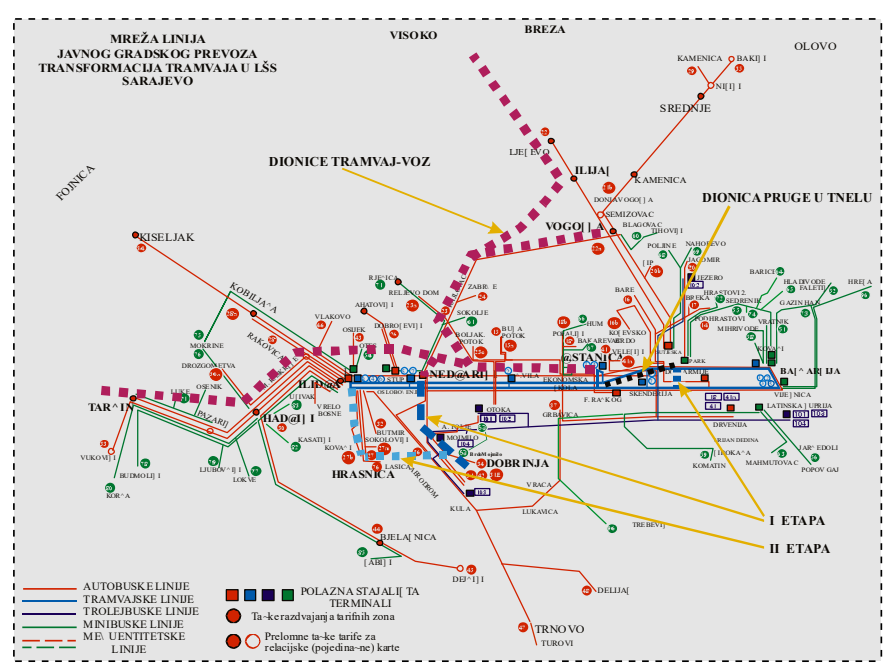

Figure 4. Railway sections by stages of LRT construction 


\section{Light rail system as a precondition for managing a high-capacity corridor in Sarajevo}

Earlier analyzes stated that at the time of the most intensive traffic volume in 1991, about 9,000 passengers were transported by trams on the most critical section $\mathrm{M}$. Dvor - Čengić Vila (section C-C, Figure 1), or 116,000 during the whole day.

As an absolute maximum, the expected transport requirements on the critical section in the future should expect 20,000 passengers per hour. From the above examples in the world, it can be seen that the LRT system is able to handle this number of passengers without compromising the quality of transport services.

It is certainly necessary for the LRT system to be able to meet transport needs over a longer period of time, or as it is often called "long term future". The capacity of the system is the product of the unit capacity (vehicle or traintrain) and the frequency of the train. It is considered that the LRT system can provide good regularity of movement up to a frequency of 40 rolling stock per hour (interval of 90 seconds). Any increase in frequency calls into question the regularity of movement, one of the basic parameters of quality LRT.

Capacity increase accompanied by increased transport comfort, because it is assumed that in the near future standing passengers will require more free space, so that with 8 passengers per square meter, comfort will increase to the value of 5 passengers per square meter, which in many developed countries is considered the standard. It is also necessary to multiply the driving units in two and in the final phase in three driving units in the near future. The SATRA3 vehicle can serve as a basis for the capacity calculation, which is similar in its characteristics to most modern vehicles, about 30 meters long and with a capacity of 300 passengers and 214 passengers.

It is clear that the expected capacities can be achieved provided that the stations are adapted and adjusted to the expected lengths of the rolling stock.

On the part of the route from Ilidža to Marijin Dvor, as well as on all new sections, there will be no problems to equip station platforms - platforms 60 to 70 meters long. Wherever possible, spare space should be left for a maximum projected capacity of 3 vehicles or 90 meters. If it requires special works and costs, the extension of these stations should be left for later.

On the part of the route from Marijin Dvor to Skenderija (ie a possible central terminal in Radićeva Street), maximum station lengths of 60-70 meters should be enabled.

On the part of the existing route from Radićeva Street to Baščaršija, it will be very difficult to provide stations 30 meters long. Due to the spatial limitations on this part of the route, the impossibility of giving full priority, the conversion of the existing tram into the LRT system is practically impossible.

The maximum capacity in the center can be achieved by building independent, presumably, underground sections, with stations 60-70 meters long and leaving opportunities for easy extension to 90 meters.

The introduction of priorities at signalized intersections is one of the most priority measures. Its realization increases the speed of movement and regularity of vehicles, which directly affects the attractiveness of tram transport. In addition, increasing the speed increases the efficiency of fleet utilization. The introduction of priorities will give the greatest effects on the section from Ilidža to Marijin Dvor, because the railway is completely separated. In the part from Marijn Dvor to Radićeva Street, greater priority effects are possible only if the tram line is maximally separated. Separation can also be done with overhanging curbs, or at least with a special road texture, on which the movement of trams and other special vehicles is allowed. It is recommended to introduce absolute priority at all intersections from Ilidža to Marijin Dvor.

After the intersection with Radićeva Street, any further crossing of the intersection towards Baščaršija is difficult, so only a minimal number of vehicles should be allowed to pass from Radićeva Street. In addition to the introduction of priorities, as a basic measure, the number of left turns should be reduced and converted into a system of three successive right turns.

In the cities of Western Europe, where priority has been introduced at intersections, an increase in the exploitation speed by $20-25 \%$ has been achieved. If the priority in Sarajevo were introduced at 27 crossings over intersections, observed for each individual direction, ie at 16 intersections, the roughly observed effects would be the following:

1. In the case of the introduction of partial priority, the average savings would be 20 seconds per pass, and the average speed and effects expressed through the increase in frequency (with the same number of vehicles) would be $11.7 \%$

2. In case of introduction of full priority, the average saving would be 30 seconds, and the speed would be higher by $18.6 \%$.

Places to change One of the ways to establish an integrated traffic system is to regulate important checkpoints. The connection between bus platforms and LŠS stations should be short and safe for users. Access to transfer points for residents of local buildings should be simple and safe.

Intersection points should be formed in small commercial centers, with small but functional premises, 
which would meet the needs of passengers in their daily lives.

If traffic analyzes show that the introduction of priorities at intersections in the zones of intersections is not easy to implement, given the intensity of other traffic flows, the possibility of forming a intersection in two levels should be considered. To justify this, it is necessary to superimpose the traffic effects and economic benefits of building a commercial space.

A rough analysis of the effects of the introduction of new platforms with a height of $30-35 \mathrm{~cm}$, shows that savings of $8.7 \%$ are possible during the turn, through faster entry and exit of passengers and thus shorter vehicle retention. Together with the introduction of absolute priority, it is possible to increase the efficiency of the transport system compared to the existing situation by $28.9 \%$.

Park and Ride (P\&R) [2] Increasing the speed of transport with LRS would create conditions for greater competitiveness of JGPP in relation to private cars. The justification for introducing a P\&R system would exist in three locations.

In the first place would be the introduction of a P\&R system near the tram terminal in Ilidža. With the favorable price of public city parking and parking, passengers could park their cars next to the tram station in Ilidža and continue with LRT. This locality could satisfy travelers from the municipalities of Ilidža, Hadžići and partly Novi grad and Trnovo. The Otoka and Marijin Dvor sites are also places where it would be justified to introduce $P \& R$, Figure 5.

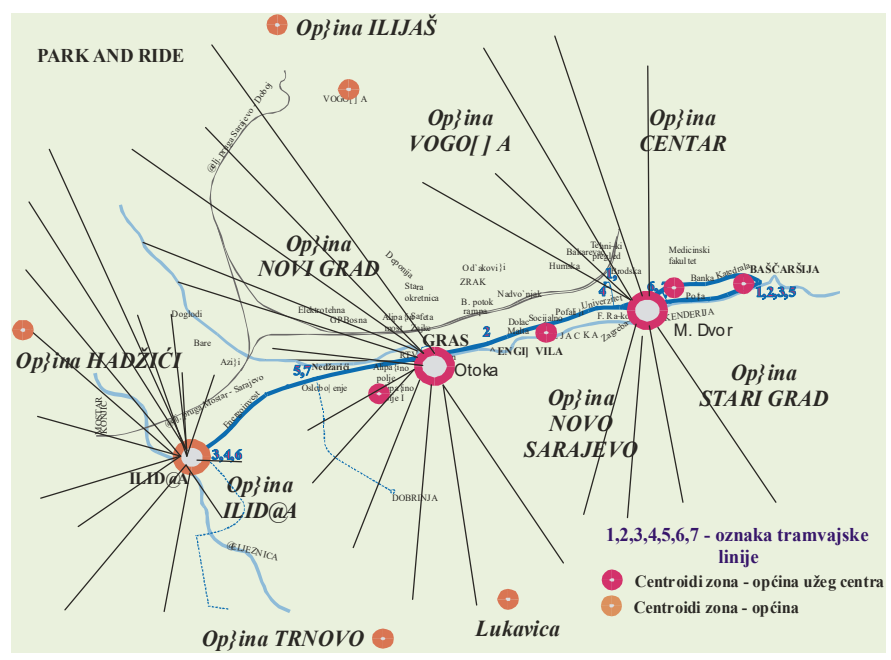

Figure 5. P\&R system location plan in Sarajevo

With the introduction of the P\&R system, the problem of air pollution in Sarajevo by passenger cars would be reduced to a minimum.
Fleet modernization The current development programs of the GRAS company have successfully considered the concept of fleet modernization. Since 2002 the orientation was on the reconstruction of existing vehicles, and due to limited financial possibilities, the renovation of 60 articulated trams according to the SATRA2 program was suspended with 15 completed vehicles. Further efforts to modernize the vehicle fleet should focus in particular on training SATRA3 doublearticulated vehicles with improvements in SATRA4 or procuring new vehicles.

Modernization of tracks and switches is necessary. Choosing the optimal track structure is not easy to make given the limited budget. It is recommended to use the track construction used during the reconstruction of the tram track in Budapest. In the part from Marijin Dvor to Baščaršija and from Baščaršija to the Holiday In hotel, in 2005 and 2012, a railway was built according to LRT standards. The track, which is used exclusively by tram and LRT, (section Ilidža-Marijin Dvor) can be opened in gravel on concrete sleepers.

The power supply system needs to adjust its capacities to the increased volume of traffic and the changed structure of the vehicle fleet. Connections of rectifier stations to the high voltage network should be improved in order to reduce power failures. The remote control system of substations together with the introduction of the braking energy recovery system can lead to a reduction of energy consumption by $30-40 \%$ due to the high degree of overlap of all lines. Measurements were performed on the SATRA2 tram and energy savings of $45-50 \%$ were found.

The charging system must enable the selection of attractive tariffs, but at the same time reduce the loss of income due to a larger number of passengers with invalid tickets. The use of a semi-closed passenger access system should be considered. This means that at certain stations with significant passenger flows, they are channeled in this way.

Management system The system of central management of public passenger transport in Sarajevo could be implemented in phases.

The first phase should include the installation of the system in tram traffic. This includes the construction of a facility for the accommodation of traffic management equipment (headquarters) of both tram and other modes of transport in Sarajevo

Phase II installation of the system in trolleybus, bus and minibus traffic. This phase will probably be realized in several stages depending on the available funds.

The current state of public transport (traffic volume, traffic disturbances, vehicle correctness, management system) requires an integral solution for the management of the public passenger transport system. 
The goals of building the system are:

- Establishment of complete and efficient control over the network of public utility lines and vehicles on it

- Covering the entire network of lines with the central traffic management system

- Increasing the level of transport quality

- Providing timely information to service users

- Reduction of the required system response time

- Reduction of traffic management costs (number of employees is smaller)

- Reducing the negative impact of public urban transport on the environment.

The expected effects are:

- The maintenance of the planned intervals of vehicle movement has been ensured

- Quick and easy intervention in case of traffic jams

- Effects of savings through more rational use of transport capacities

- Reduction of the number of dispatching staff

- Reduction of maintenance costs of dispatching facilities

- It is possible to quickly produce statistical reports on the operation of vehicles and passenger requirements

- Reducing the negative impact of public urban transport on the environment.

\section{Investments and financing LRS}

The decision to invest in a light rail system project in Sarajevo should be based on appropriate methods for evaluating projects, ie investment decisions. One-criteria or intuitive decision-making in the present tense can only be accidentally correct, both because of very complex relations (economy, social aspects, space, environment) and interactive relationships. In this case, the practice should be avoided that the criterion - profit is the dominant criterion, but to take into account other benefits from the project - benefit, e.g. full employment, minimum energy consumption, technical and technological reliability, environmental safety, quality of service, etc.

The costs of investing in the system include the costs of investing in vehicles, roads (railways), equipment and supporting systems, and facilities.

The most commonly used methods of financing are:

- Financing from the city budget

- Bonds

- Bank loans
- Commercial financing

- Contribution from funds for the development of transport infrastructure

- PPP - Public and Private Partnership (PPP - Public

Private Partnership).

Negotiations related to financial loans should be conducted at a competent level, in order to be able to talk about the conditions of providing loans for project implementation.

\section{Conclusion}

The state of the public transport system in Sarajevo dictates the need for its transformation. The priority is the transformation of the tram system into a more advanced system, and as an optimal solution is the system of Light Rail Transport - LRT. By building LRS and clearly defining the management system, huge effects are obtained in relation to the invested funds (in relation to investments in the metro).

The expected effects are within the limits of the effects of the introduced systems in cities of approximate size of Sarajevo. For transport requirements up to 20,000.00 passengers per hour LRT has $20-30 \%$ of the cost of building a subway, and $70-80 \%$ of the attributes of a conventional subway.

Further activities in the process of improving tram transport should be planned in the direction of:

- Formation of the traffic model of Sarajevo in order to simulate changes in the organization and exploitation of traffic or construction of new sections

- Research of existing and potential passengers in order to determine their sensitivity to higher transport costs while providing better transport quality

- More detailed engineering tests for new routes and stations

- Finding an acceptable source of funding.

For the introduction of LRT in Sarajevo, it is now necessary, in accordance with the recommendations given in this paper, to prepare detailed documentation and plan clear units for each period, so that the plan itself is imposed on future authorities as an equal obligation, not as a new area of research from scratch. every four years. It is especially important to emphasize that there is a risk that some of the authorities will not make a decision on the construction of a very expensive variant, e.g. Metro system, which will not be possible to implement in a period of four years, and the next authorities do not support it. 


\section{References}

[1] R. Buehler, J. Pucher, "Sustainable transport in Freiburg: lessons from Germany's environmental capital," International Journal of sustainable transportation, vol. 5, no. 1, pp. 43-70, 2011.

[2] M. Mehanovic, "Planiranje ponude usluga u gradskom prometu putnika," Faculty of Traffic and Comunication in Sarajevo, University of Sarajevo, 2011.

[3] R. Buehler, J. Pucher, "Demand for public transport in Germany and the USA: an analysis of rider characteristics," Transport Reviews, vol. 32, no. 5, pp. 541-567, 2012.

[4] M. Mehanovic, "Public Transport of Passengers Main Resource of Sustainable Urban Mobility in Sarajevo," Journal of Mechanical and Civil Engineering (IOSR-JMCE), vol. 17, no. 2, pp. 44-56, 2020.

[5] S. Kim, G. F. Ulfarsson, J. T. Hennessy, "Analysis of light rail rider travel behavior: Impacts of individual, built environment, and crime characteristics on transit access," Transportation Research Part A: Policy and Practice, vol. 41, no. 6, pp. 511-522, 2007.

[6] T. Alde, J. Edelenbos, A. Gianoli, “Adapting urban lightrail transport to the African Context: A process conducted by transport authorities and Chinese rail corporations in AddisAbaba, Abuja, and Lagos," Urban Science, vol. 3, no. 4, pp. 117, 2019.

[7] D. Catling, S. McIntosh, G. Stefanovics, J. V. Rohr, "Guidelines for Selecting and Planning a New Light Rail System,“ 2001.

[8] M. Mezghani, "Study on electronic ticketing in public transport. Final Report, “ EMTA - European Metropolitan Transport Authorities, 2008.

[9] Y. Crozet, J. Coldefy, "Mobility as a Service (MaaS): a digital roadmap for public transport authorities," 2021.

[10] M. Novales, A. Orro, M. R. Bugarin, "Tram-train: new public transport system, “ Transportation Research Record, vol. 1793, no. 1, 2002.

[11] M. Mehanović, "Planiranje u saobraćaju, prevozu i komunikacijama“, Faculty of Traffic and Communications, University of Sarajevo, 2017. 